\title{
Improving Policy Coordination Across the Water, Energy, and Food, Sectors in South Asia: A Framework
}

\author{
Golam Rasul* and Nilhari Neupane \\ International Center for Integrated Mountain Development, Kathmandu, Nepal
}

Land, water, and energy resources are coming under unprecedented pressure owing to growing populations, urbanization, industrialization, and changing lifestyles, food habits, and climate. Generally, sectoral approaches are taken to address these challenges that overlook the close linkages between the water, energy and food sectors and resultant cross-sectoral implications. The result is an uncoordinated and unsustainable use of resources that increasingly threatens water, energy, and food securities in many parts of

OPEN ACCESS

Edited by:

Wenfeng Liu,

UMR8212 Laboratoire des Sciences du Climat et de l'Environnement (LSCE), France

Reviewed by: Tafadzwanashe Mabhaudhi, University of KwaZulu-Natal, South Africa

Zarrar Khan,

Joint Global Change Research Institute, United States Dandan Ren,

Hebei Normal University, China

*Correspondence: Golam Rasu

golam.rasul@icimod.org; golam.grasul@gmail.com

Specialty section: This article was submitted to Water-Smart Food Production, a section of the journal Frontiers in Sustainable Food Systems

Received: 03 September 2020 Accepted: 26 January 2021

Published: 24 February 2021

Citation:

Rasul G and Neupane N (2021) Improving Policy Coordination Across the Water, Energy, and Food, Sectors in South Asia: A Framework. Front. Sustain. Food Syst. 5:602475. doi: 10.3389/fsufs.2021.602475 the world. To enhance sustainability in resource use, the use of water-energy-food nexus (WEF) approach has been advocated in recent years. Despite its conceptual appeals, the practical application of this approach in government planning and decision making has remained limited in part due to lack of an appropriate framework to operationalize the concept as a planning and decision-making tool. This paper suggests a framework for operationalizing the nexus concept in planning and decision-making, using South Asia as an example. The framework outlines four steps to evaluate and prioritize nexus issues to improve cross-sectoral planning and coordination using three broad criteria to assess the impact of actions in one sector on another: synergies (co-benefits), trade-offs (externalities), and neutrality. A cross-sectoral coordination body provides the institutional mechanism for ensuring coordination of policy and action. The four steps are: (a) harmonizing policy goals, (b) identifying interactions and critical connections between these sectors in an integrated manner, (c) assessing compatibility of nexus objectives and policy instruments, and (d) screening programs, projects, and investments against nexus goals. The framework is expected to help governments in coordinating the actions of diverse actors across the water, energy and food sectors and designing policies and programs that address trade-offs, while increasing production sustainably, conserving natural resources, and enhancing -water-energy-food nexus outcomes.

Keywords: food-water-energy nexus, policy coherence, policy coordination, sustainable development goals, South Asia

\section{INTRODUCTION}

The combination of increasing population, urbanization, industrialization, changing lifestyles, and consumption patterns is putting pressure on land, water, and energy resources (FAO, 2011; Rasul, 2014; Albrecht et al., 2018; Markantonis et al., 2019; Katz et al., 2020; Liu et al., 2020). These resources are closely interlinked and the pressure is leading to increasing concern about the sustainability of water, food, and energy production (OECD, 2014). Global water use has been 
increasing at twice the rate of population growth (United Nations, 2015). But about $30 \%$ of people globally still lack access to safe water; and increasing risks of achieving universal and equitable access to safe and affordable drinking water for all by 2030 as committed by global community in sustainable development goals (SDGs) six. Projections indicate that global water demand will increase by around $55 \%$ by 2050 (UNESCO, 2020 ), with more than $40 \%$ of the global population suffering from severe water stress by 2030 (United Nations Water, 2018) and a potential 700 million people displaced as a result of intense water scarcity (United Nations, 2015). Similarly, the number of people suffering from food insecurity has been growing rapidly, rising from 785 million in 2015 to 822 million in 2018 (FAO, 2019). At the same time, food production has become more water and energy intensive due to increasing intensification and mechanization of agriculture and reliance on agro-chemicals, as well as the expansion of irrigation-particularly groundwater irrigation (Khan and Hanjra, 2009; Rasul, 2016). About 30\% of total global energy is used in food production, processing, and transportation (FAO, 2011), while about $70 \%$ of global freshwater withdrawals (often reliant on energy) are also used in agriculture (Hoekstra and Mekonnen, 2012). Thus, energy availability directly influences food production (FAO, 2011). However, at present, around a billion people do not have access to electricity, and global energy demand is expected to rise by $25 \%$ by 2040 (International Energy Agency, 2019) and access to affordable, reliable and modern energy services envisioned in SDG7 will be at risk. As the demand for water and energy increases, there is a growing pressure to improve the efficiency of water and energy use in agriculture and food production. In many regions, water resources are used inefficiently and unsustainably and groundwater is overexploited for food production (Alauddin and Quiggin, 2008; Pingali, 2015; Rasul, 2016).

For many years, sector analysts have emphasized the need to increase productivity in individual sectors and boost food and energy production to meet the pressing challenges of increased demand (International Institute for Sustainable Development, 2013; Pahl-Wostl, 2017). However, treating them independently of each other can result in increased resource scarcity and lead to ineffective or even counterproductive policies and strategies (Scott et al., 2011; Nilsson et al., 2012; Nhamo et al., 2018; Markantonis et al., 2019). It is important to understand and manage the synergies (where actions in sector have positive effects on another sector) and trade-offs (where progress in one hinders progress on another) between and among the sectors (Cai et al., 2016; Rasul, 2016; Putra et al., 2020). One way of addressing this is to use an integrated nexus approach (Bazilian et al., 2011; Leck et al., 2015; Pahl-Wostl, 2017; Nhamo et al., 2020). The nexus concept provides a systems approach that recognizes the inherent interdependencies of the water, energy, and food sectors for resource use and provides tools to assess the trade-offs and synergies among the interconnected sectors (Bazilian et al., 2011; Hermann et al., 2012; Prasad et al., 2012; Leck et al., 2015).

The nexus concept for water, energy, and food (WEF) security has received considerable attention from the global community (International Institute for Sustainable Development, 2013; Liu et al., 2019; Markantonis et al., 2019). In 2011, both the World
Economic Forum and the Bonn Nexus Conference promoted the concept (Bazilian et al., 2011). While the WEF nexus approach is intellectually appealing, practical application in government planning and decision making has remained limited, one of the main reasons being the lack of an appropriate framework to operationalize the nexus concept as a planning and decision making tool (Lele et al., 2013; Rasul, 2016; Weitz et al., 2017; Markantonis et al., 2019; Nhamo et al., 2020). Sectoral agencies generally prefer to work within their sectoral areas, and bringing the sectors together is a challenging task that needs a systematic approach and framework that provides actors with a common ground and facilitates coordination across the sectors (Bizikova et al., 2013; Lele et al., 2013; Markantonis et al., 2019).

As in many other regions, food production in South Asia has become increasingly water and energy intensive (Rasul, 2016). Poor sectoral coordination and institutional fragmentation have triggered an unsustainable use of resources which threatens the long-term sustainability of water, energy, and food security, and poses challenges to achieving the Sustainable Development Goals (SDGs) in the region (Rasul, 2016; Stephan et al., 2018; United Nations, 2019). The crisis emerging from COVID-19 will further exacerbate the nexus challenges in many developing countries, as COVID-19 impacts on human health and well-being, and the demand for integrated action and policy framework in response includes access to nutritious food, adequate safe water, and energy (Rasul, 2020, 2021; Schmidhuber et al., 2020).

Although there have been significant advances and technological innovations in the development of tools in nexus assessment, most of the nexus approaches focus on developing technologies and tools to quantify nexus relationships and assess trade-offs (Albrecht et al., 2018; Liu et al., 2018). While these tools and technologies are very useful, it is critical to have coordination mechanisms to bridge the divide between the water, energy, and food sectors and bring them together for planning, prioritization, and resource allocation (Halbe and Knüppe, 2015; Weitz et al., 2017). The prevailing technical orientation framing the nexus approach is inadequate for cross-sectoral coordination in planning and prioritization (Halbe and Knüppe, 2015; Al-Saidi and Elagib, 2017; Weitz et al., 2017). As yet, there is no framework available for translating nexus ideas into concrete steps for governments to apprise polices and evaluate nexus issues and options (Scott et al., 2011; Liu et al., 2017; Simpson and Jewitt, 2019).

Significant challenges remain in finding ways in which sectoral policies can be better integrated, designing a framework that can be used in cross-sectoral coordination, and finding tools and mechanisms that can be employed. How can we move from a sectoral approach to a more integrated approach and develop cross-sectoral strategies? In this paper, we attempt to develop a framework that can provide a basis for developing a common ground for strengthening cross-sectoral coordination in planning and prioritizing activities and for resource allocation and investment, using South Asia as an example. This paper is structured in seven sections. Following this introduction, section 2 discusses the paper's approach and methodology. Section 3 presents the interconnected challenges of water, energy and food security in South Asia. Section 4 discusses 
policy issues related to nexus governance including crosssectoral impacts followed by policy options and innovations for addressing nexus challenges are presented in section 5 . Section 6 outlines the proposed framework for strengthening cross-sectoral coordination followed by the conclusions in section 7 .

\section{APPROACH AND METHODOLOGY}

As the main focus of this study is to develop a framework to improve policy coordination across WEF sectors, this study has been guided by three broad research questions: (a) How can we move from a sectoral approach to a more integrated approach and develop cross-sectoral strategies to manage tradeoffs and synergies in WEF? (b) What policy and institutional mechanism are required to manage nexus challenges? (c) Can a framework be developed to evaluate nexus issues and options and improve cross-sectoral coordination in planning, implementing and prioritizing activities and investment as a response to nexus challenges? While literature on WEF nexus is increasing globally, the understanding of policy and cross-sectoral coordination is limited, particularly in South Asia (Rasul, 2016).

\section{Collection of Information}

To collect literature, we began with keyword search. The search string terms included combinations of "water-energy-food nexus," "cross-sectoral coordination," "nexus policy framework," "cross-sectoral policy linkages," "nexus framework, models and tolls," and "South Asia." We limited our search between 2010 and 2020. We began the search with Scopus, however as many journal articles do not touch upon cross-sectoral policy coordination, we expanded our search to Google Scholar and ResearchGate to fill in the gaps. This resulted in a list of 705 documents. We then analyzed the literature based on following inclusion and exclusion criteria. The main inclusion criteria for the articles were to: (1) cover water-energy-food policy coordination; (2) cover any aspects of WEF planning, coordination, and prioritization and (3) to be published in the English language. The main exclusion criteria were: (1) literature that are not directly related to the WEF nexus; (2) literature that are not related to or deal with cross-sectoral policy coordination; (3) literature that are not published in the English language.

For analysis, we first examined the titles and abstracts, and then explored the full texts, after which, unsuitable articles were removed. In total, 113 documents were found suitable for the study. These 113 documents were studied in detail, analyzed and used in the study. Our analysis and basis for developing a framework, has been guided by the three questions mentioned above which have been aimed at understanding crosssectoral policy linkages, the way they operate as well as in identifying policy and institutional options and innovations that improve synergies and reduce trade-offs and brings together a diverse stakeholders around a common vision of addressing WEF nexus challenges.

\section{THE WATER, ENERGY, AND FOOD SECURITY NEXUS IN SOUTH ASIA}

South Asia is the home of world's largest number of hunger and malnourished population (FAO, 2019). Some 277 million people are undernourished in South Asia, and the number is expected to drop only slightly to 230 million by 2030 . The region is home to 1.5 billion people who depend predominantly on agriculture as their main source of livelihood. The agricultural sector is responsible for $90 \%$ of total freshwater withdrawals and 15-20\% of energy use (Shah et al., 2004; Rasul, 2014), and makes a significant contribution to greenhouse gas emissions. Of the 204 million ha of cultivated land, close to half (93 million ha) is irrigated, 34 million ha (37\%) from surface water, 51 million ha $(55 \%)$ from groundwater, and 8 million ha (9\%) from a combination of surface and groundwater (FAO, 2018). Irrigated agriculture not only provides food for millions of people, it also employs millions of people providing them with livelihoods and food security.

Food production in South Asia has become increasingly water and energy intensive. Currently more than 60 million ha of agricultural land is used to grow rice, the most important staple. Rice is water intensive, requiring two to three times more water than wheat and other cereals. The area used for wheat cultivation, another important staple, increased nearly 2 -fold to 50 million ha between 1960 and 2018 as a result of the development of groundwater irrigation (FAO, 2018). Overall, there has been a sharp increase in crop yield in the region. For example, in India, food grain production jumped from 108 million tons in the 1960s to 265 million tons in 2015 (Malik, 2016). This increase has been made possible through the expansion of irrigated agriculture, mechanization, and the use of agrochemicals, all of which have implications for water and energy use.

The per capita land availability has sharply decreased to present day values of $0.12 \mathrm{ha} /$ capita compared with a global average of $0.20 \mathrm{ha} /$ capita (World Bank, 2018). This has compelled farmers to increase the use of agricultural inputs such as water, fertilizer, and pesticides to increase productivity. At the same time, surface irrigation coverage decreased from 49 million ha in 1999 to 37 million ha in 2009-while groundwater irrigation, which requires more energy for pumping, increased from 36 million ha to 51 million ha (FAO, 2016). Energy is also needed to operate the agricultural machinery used in land preparation, harvesting, and threshing, and post-harvest activities such as drying, milling, packing, storing, and processing, as well as for transportation of agricultural inputs and products and producing fertilizers and pesticides. In India, agriculture accounted for almost $20 \%$ of total power consumption in 2009 , with percentages as high as $40 \%$ in Haryana, and close to $30 \%$ in Gujrat and Punjab states (Kumar et al., 2011). Fossil fuel is widely used as an energy source in agriculture, and agricultural intensification has resulted in a 3.5-fold increase in greenhouse gas emissions over the last 40 years, from 1 million $\mathrm{kt}$ in 1970 to 3.6 million $\mathrm{kt}$ ( $\mathrm{CO}_{2}$ equivalent) in 2012 (World Bank, 2018).

Agriculture is thus the core component in the water-landenergy linkages in South Asia (FAO, 2014). To feed their 
growing populations, South Asian countries have pursued policies for achieving self-sufficiency in rice and wheat based on increased use of water, energy, and agrochemicals (Alauddin and Quiggin, 2008) and achieved through heavy subsidization of water and energy (Atapattu and Kodituwakku, 2009). While these policies have contributed to increased food production, they have also led to degradation of the natural environment and environmental resources such as land, soil, and water. Agricultural intensification has resulted in the depletion of groundwater, pollution of water and soil, and loss of biodiversity (Alauddin and Quiggin, 2008). The high dependence on energy has also made food production increasingly vulnerable to changes in price, access, and availability of energy (Rasul, 2014). There are an estimated 21 million water pumps in South Asia, with half powered by subsidized electricity and the remainder by diesel (Shah et al., 2004). Farmers still use diesel pumps because of the lack of access to electricity on many farms and the poor quality of the supply. The price volatility of fossil fuels in the global market mostly affects the farmers who use diesel pumps.

Agriculture and food production have become increasingly dependent on water and energy availability. In spite of the inherent interconnections between water, energy, and energy production, the sectors largely work in an isolated way, without taking into account the cross-sectoral implications. With the spread of corona virus, South Asian countries are expected to face shocks in the food and agriculture sectors from the impacts of COVID 19 (Schmidhuber et al., 2020), and there is now a major concern as to whether countries will have sufficient food and water following the disruption in supply.

The crisis emerging from COVID-19 is expected to further exacerbate the nexus challenges (Rasul et al., 2020). Many countries in South Asia already face difficulties in providing, households with access to safe water. A large number of rural households (23-42\%) obtain water from outside their compound (ICIMOD, 2020). Many households in South Asia (16-53\%) have insufficient soap and water for hand washing, while in Afghanistan almost $42 \%$ of households are compelled to use unsafe drinking water (ICIMOD, 2020; Rasul et al., 2020). This has increased the risks and vulnerability of households to COVID-19 and limits their options to respond (Rasul, 2021). The link between the COVID-19 pandemic and several SDGs, including SDGs 1, 2, 3, and 6, highlights the importance of integrated action (Rasul, 2020). There is a pressing need to develop an integrated approach to water, energy, and food security to ensure the long-term sustainability of the irrigation and agriculture system.

\section{POLICY ISSUES IN NEXUS GOVERNANCE The Current Agricultural Policy Approach}

All the South Asian countries have adopted various direct or indirect policy measures to support farmers to increase food production (Pingali, 2015; Rasul, 2016). Specifically, the measures focus on increasing the production of the major food crops, mainly rice and wheat, and include subsidies for energy, irrigation, seeds, and agro-chemicals. Various measures have been undertaken to make use of surface and groundwater by expanding irrigation facilities and installing shallow and deep tube wells for groundwater extraction (Barker and Molle, 2004; Pingali, 2015; Rasul, 2016; Tyagi and Joshi, 2019). Policy support in the form of input subsidies and market and infrastructure development has significantly changed cropping patterns and farming practices. The area of irrigated rice and wheat has increased significantly in all South Asian Countries, while the mechanization of water extraction and distribution using diesel or electricity has led to a sharp increase in both the use of energy and the emission of greenhouse gases (GHGs) (Ahmed et al., 2013, FAO, 2018, World Bank, 2018). Over 30\% of GHG and 20\% of methane emissions come from the agricultural sector (Gilbert, 2012). Substantial increases in crop production have also been achieved through policy support for the adoption of high yielding varieties (HYVs) particularly for rice, wheat, and maize. But these varieties have replaced traditional food crops and legumes which has resulted in a narrowing of both crop and dietary diversity, with a resultant negative impact on nutritional security (Pingali, 2015; Rasul, 2016; Rasul et al., 2018).

The water resources development strategy in South Asian countries has focused mainly on the expansion of irrigation facilities to increase food grain production (Hasanain et al., 2012; Rasul, 2016). Water for irrigation is provided free of cost, and the delivery is also highly subsidized (Hasanain et al., 2012; Rasul, 2016). Different forms of charging are practiced in different countries and within the same country. For example, in Bangladesh, farmers were charged only USD 6 per hectare to cover annual operation and maintenance costs for irrigation, $18 \%$ of the actual cost of USD 34 per hectare with the remainder subsidized by the government (FAO, 2011). Similarly, the average subsidy from 2004 to 2008 for a major irrigation project in South India was USD 579 million (Palanisami et al., 2011), while in Nepal, operation and maintenance costs were charged at USD 45 per hectare against an actual cost of USD 42 per hectare (FAO, 2012) and in Pakistan the charges were USD 5.5 per hectare compared to actual annual costs per hectare of USD 23 (Qureshi et al., 2010; Planning Commission of Pakistan, 2012).

Energy for irrigation has also been heavily subsidized to encourage the use of irrigation facilities. Electricity is provided at a nominal cost or even free of charge in some states in India such as Punjab, Haryana, and Andhra Pradesh. In Andhra Pradesh, farmers pay only INR 0.04 per kWh compared to actual costs of INR 3.40 per kWh (IFPRI, 2007). The electricity tariffs in Andhra Pradesh, Kerala, and Gujrat are estimated to range from 0.4 to 1.5 US cents per kWh compared to 5-8 cents actual cost (Shah et al., 2004).

In general, electricity tariffs for farmers in India amount to $<10 \%$ of the cost of supply (Badiani et al., 2012). Provision of this highly subsidized electricity has resulted in a significant increase in the area dedicated to cereals in Punjab (from 50 to $75 \%)$, mostly to produce water-intensive rice (Mukherji et al., 2011). The electricity subsidy for agriculture In Pakistan is PKR 3.50 per unit of electricity consumed (Planning Commission of Pakistan, 2012). Similarly, in Bangladesh, there is a subsidy of 400 Taka per acre for diesel-operated irrigation pumps (Asaduzzaman et al., 2009). Cheap energy and increased use of groundwater for irrigation have significantly increased the 
agricultural share of electricity consumption (IFPRI, 2007). The cheap energy not only increased energy demand but also made extraction of groundwater cheaper, which led to inefficient use of water and energy and over extraction of ground water. As a result, between 1973 and 2013 South Asia's irrigated area almost doubled from 49.6-98.0 Mha and 90\% of this ground water irrigation (Shah et al., 2018). This in turn has affected environment and intensified the trade-offs between water and energy. The intensive agriculture has accelerated the use of water and energy in food production, which is now raising serious concerns related to land degradation, water pollution, eutrophication, groundwater depletion, salinity, waterlogging, arsenic contamination, invasion of alien species and loss of biodiversity, environmental degradation, and negative impacts on human health (Lal, 2011; Pingali, 2012).

\section{Investment in Water, Energy, and Food Infrastructure}

Despite growing concerns and increasing recognition of the interconnected nature of water, energy, and food, investment and policy decisions remain predominantly sectoral. Of 3,305 big water infrastructure projects in South Asia recorded by Aquastat in 2016 (FAO, 2016), only $12(0.4 \%)$ were multipurpose and $215(6.5 \%)$ dual purpose (irrigation +drinking, irrigation + hydropower or irrigation +flood control). The great majority (3,078 or $93 \%$ ) were single purpose: $2,945(89 \%)$ for irrigation, 98 (3\%) for hydropower, and 35 (1\%) for drinking water.

\section{Sectoral Policies and Their Impacts}

The current policies for intensifying cereal production focus simply on food production without taking into account the impacts on other sectors or the long-term sustainability. The major cross-sectoral and social, economic, and environmental impacts are summarized briefly in Table $\mathbf{1}$.

\section{POLICY OPTIONS AND INNOVATIONS FOR ADDRESSING NEXUS CHALLENGES}

Because of increasing resource scarcity and the threat of climate change, recently policy makers have given some attention to address the nexus challenges and a number of policy, institutional, and regulatory measures have been introduced in South Asian countries to address the nexus challenges. Pakistan is trying to ration water by charging higher fees for more water intensive crops such as sugarcane (Planning Commission of Pakistan, 2012). Some Indian states are trying to regulate and ration electricity in agriculture by introducing random power cuts, while others are gradually reducing the electricity subsidy for irrigation (Shah et al., 2018). To provide access to energy and replace diesel to clean energy, some states in India supported solar-powered pumps for groundwater irrigation, though concerns also raising about over-exploiting of ground water in certain areas (Shah et al., 2018; Beaton et al., 2019). In some States in India, farmers can sell the excess solar power to grid and earn additional income. This has provided incentive for efficient use of energy and resultant rational use of groundwater (Shah et al., 2018).

The Jyotigram Yojana in Gujarat (a scheme for rural lighting) provides a good example of the aims and actual impacts. Electricity users are divided into agricultural and nonagricultural, and electricity for irrigation is rationed to limit water use (Mukherji et al., 2012; Shah, 2012). The approach has helped to increase the quality of the power supply for normal users, but it has not succeeded in motivating farmers to adopt energy and water saving technologies, while the segregation of electricity lines for agricultural use requires a huge capital investment in infrastructure, which is beyond the capacity of many states. Other efforts are underway to increase farmers' participation in irrigation water management, which helps recover the cost of water fees as well as ensuring better distribution and management of irrigation water (Hasanain et al., 2012; Shah, 2012). Notable efforts have been made in Andhra Pradesh with the enactment of the Farmers Management Irrigation Act 1997, which promotes participatory irrigation management (Gandhi and Namboodiri, 2009). However, except in Andhra Pradesh and West Bengal, the participatory irrigation management system has remained marginal in India (Gandhi and Namboodiri, 2009; Lele et al., 2013) due to weak institutional capacity, limited support from government irrigation agencies, limited authority, and unequal distribution of power.

Different policy innovations both regulatory and market based instruments are now being developed to address nexus challenges. Technological advancement have made possible conjunctive use of water, installation of pre-paid meter with smart cards, installation of smart chips in ground water pumps. Private sectors also coming forward with financial and technical supports (Sarni, 2015). Table 2 provides some examples of nexus focused policy innovations in South Asia and beyond.

\section{FRAMEWORK FOR IMPROVING POLICY COHERENCE ACROSS WATER-ENERGY-FOOD SECTORS}

While the WEF nexus is becoming increasingly important, the lack of an appropriate framework that can integrate the water, energy and food sectors has been a key challenge in adopting the WEF nexus approach in policy planning and implementation. Several recent attempts by scholars and development organizations have been made to develop a variety of models, tools, approaches, and analytical frameworks to assess WEF's interactions and challenges. The integrated modeling approach suggested by Bazilian et al. (2011) reflects the complex interaction between water, energy and food to inform policy decisions. Similarly, Giampietro et al. (2013) developed a multisectoral innovative accounting framework for the food-energywater nexus known as MuSIASEM (Multi-Scale Integrated Analysis of Societal and Ecosystem Metabolism) to analyze possible cross-sectoral impacts and simulate potential patterns of development. Another integrated framework, known as CLEWS framework, has been developed by the International Atomic Energy Agency IAEA (2009) to identify interacting issues among 
TABLE 1 | Sectoral policies and their cross-sectoral impacts.

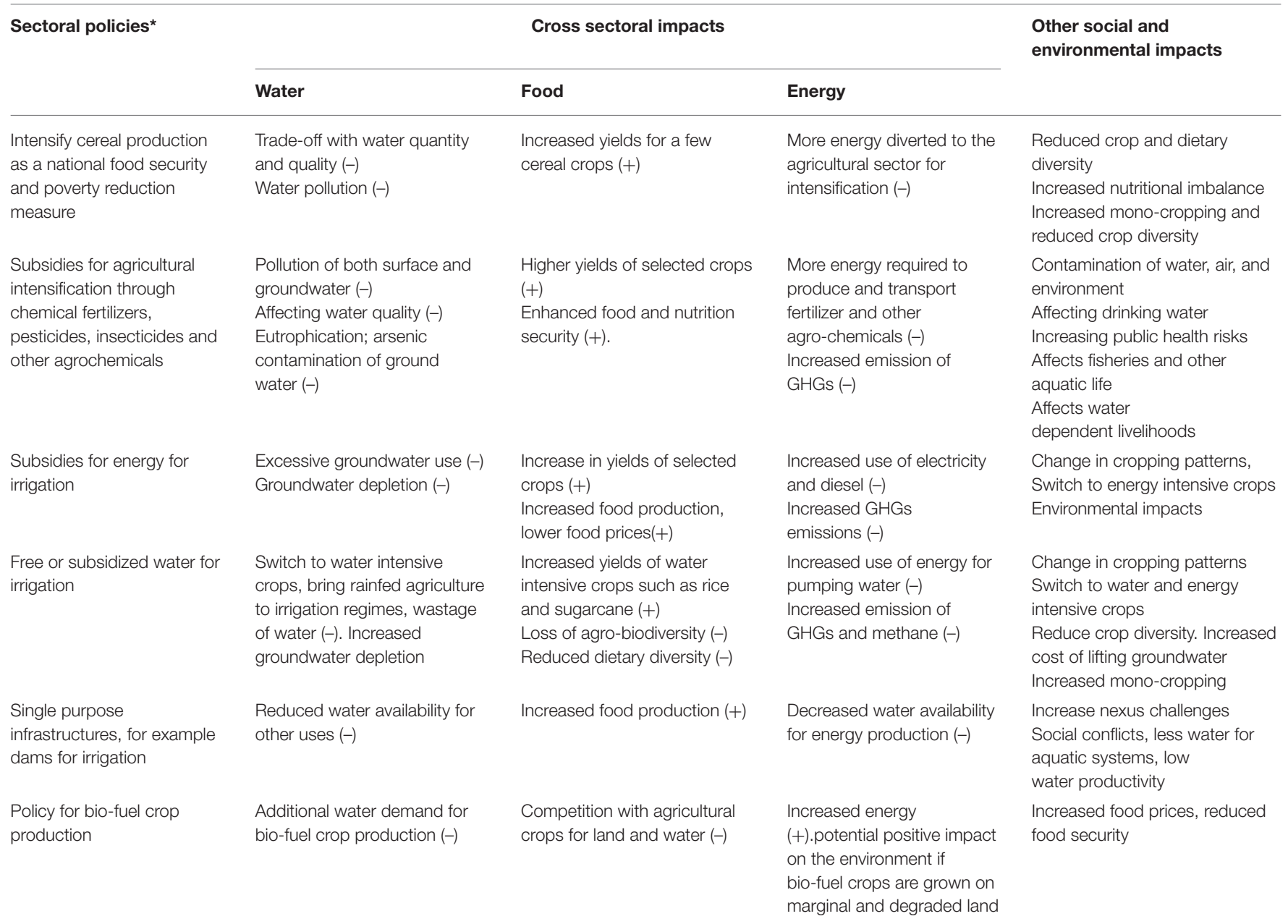

$(-)$, sign denotes trade-off; (+), sign denotes synergy.

Source: synthesized by authors from Pingali (2007), Alauddin and Quiggin (2008), Rasul (2014), Pingali (2015), and Rasul (2016).

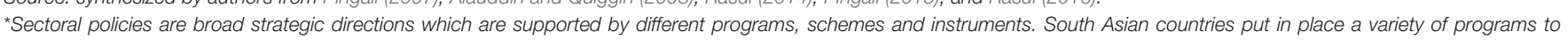

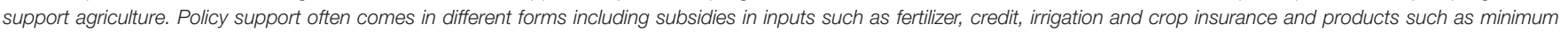
support prices, and involves different ministries and even central and state governments as in India (Gulati et al., 2018; Ramaswami, 2019).

climate, land, energy and water systems. Along with nexus interlinkages, this framework can be used for the development of future nexus scenarios. Another nexus framework proposed by Rasul (2014) focuses on ecosystem services primarily in the Himalayas and South Asia regions, highlighting the importance of ecosystem services to ensure water, energy and food security, whereas Amjath-Babu et al. (2019) presented hydroelectricity and irrigation synergies for improving the WEF nexus in the same region.

Some analytical frameworks provide interactive tools that are appropriate for the visualization of nexus connections. For example, the "Water, Energy, Food Nexus Tool 2.0" (Mohtar and Daher, 2016) assesses the interactions between WEF and generates scenarios of WEF nexus including measures of selfsufficiency and imports, and transportation methods. This tool has food as its entry point and allows for preliminary assessments of the impacts of nexus synergies and trade-offs. Its application, however, is limited to agricultural crop production and therefore does not to assess wider food production systems such as livestock, dairy production and processed foods (Kaddoura and El Khatib, 2017). Similarly, CSIRO's National Outlook Model (NOM) of Australia provides tools that incorporate data and stakeholder inputs at the national scale of Australia (Hatfield-Dodds et al., 2015). The NOM framework relies on a number of interconnected proprietary (CSIRO) models, imposing significant computational and input data requirements. Based on the input-output theory, Karnib (2017) developed a simulation model known as the Q-nexus model for assessing the direct and indirect WEF nexus interconnections using a quantitative approach.

This model is capable of quantifying the economic relationship between the WEF sectors and the requirements of each resource, as well as assessing their potential stress and adverse impacts (Karnib, 2018). An inter-disciplinary research 
TABLE 2 | Examples of nexus focused policy innovation in South Asia and beyond.

\begin{tabular}{|c|c|c|}
\hline Policy innovations & Implementation and outcome & References \\
\hline $\begin{array}{l}\text { Water allocation and } \\
\text { rationing }\end{array}$ & $\begin{array}{l}\text { Introduced in Tunisia, a semi-arid country vulnerable to droughts, with water allocated on a use } \\
\text { basis. The system succeeded in maintaining a reliable supply during a drought; } 97 \% \text { of the } \\
\text { population had access to drinking water. }\end{array}$ & Mellah, 2018 \\
\hline Rationing electricity supply & $\begin{array}{l}\text { Introduced in several states in India. The Jyotigram Yojana program in Gujarat separated the supply } \\
\text { lines for agriculture, which helped manage the load and reduce groundwater depletion. }\end{array}$ & Shah and Chowdhury, 2017 \\
\hline Water buybacks & $\begin{array}{l}\text { Payment schemes were introduced by the Spanish government to reduce water stress in the Murcia } \\
\text { Plateau with water rights provided to purchase water from other consumptive users. The scheme } \\
\text { reduced groundwater extraction and conserved water for the ecosystem and biodiversity. }\end{array}$ & $\begin{array}{l}\text { Garrick et al., 2009; Calatrava } \\
\text { and Martínez-Granados, } 2018\end{array}$ \\
\hline Solar irrigation pumps & $\begin{array}{l}\text { Introduced in India, especially in areas off the electricity grid, supported by subsidies and payment } \\
\text { schemes. In Maharashtra, users have rights to sell surplus power. } \\
\text { The pumps have increased crop productivity and reduced diesel and electricity consumption. }\end{array}$ & Gupta, 2019 \\
\hline Remote-sensing chips & $\begin{array}{l}\text { Chips that monitor and measure the extraction of groundwater have already been introduced in } \\
\text { India. Installing level sensors in pumps could limit the extraction of water after groundwater drops } \\
\text { below a certain level. }\end{array}$ & Gupta, 2019 \\
\hline Strategic investments & $\begin{array}{l}\text { A multi-purpose dam was introduced in France through the Durance-Verdon Rivers multipurpose } \\
\text { program. The dam provides water for hydroelectricity, agriculture, drinking, industry, transportation, } \\
\text { and tourism services. }\end{array}$ & $\begin{array}{l}\text { Branche, 2017; Rasul et al., } \\
2019\end{array}$ \\
\hline $\begin{array}{l}\text { Unit pricing and metering of } \\
\text { irrigation water }\end{array}$ & $\begin{array}{l}\text { New pumps with meters have been installed in some states in India to enhance energy efficiency in } \\
\text { agriculture. Farmers pay a use-based tariff leading to conservation of groundwater, a reduced carbon } \\
\text { footprint, and increased net return. }\end{array}$ & Bassi, 2014; Kumar, 2016 \\
\hline Biofuel & $\begin{array}{l}\text { Biofuel industries are growing rapidly, especially in the US and Brazil to replace fossil fuels. While } \\
\text { producing biofuels can enhance competition for land and water, when land and water are sufficient } \\
\text { and second and third generation biofuels such as cellulosic, agricultural waste, camelina, jatropha, } \\
\text { algae are used biofuels can supply energy, enhance energy security and provide environmental } \\
\text { benefits. }\end{array}$ & $\begin{array}{l}\text { Gerbens-Leenes and } \\
\text { Hoekstra, 2011; Rulli et al., } \\
2016\end{array}$ \\
\hline $\begin{array}{l}\text { Conjunctive use of surface } \\
\text { and groundwater }\end{array}$ & $\begin{array}{l}\text { Conjunctive use of surface and groundwater is practiced on more than } 70 \% \text { of the agricultural land in } \\
\text { Pakistan. Not only has it helped to solve water scarcity and reduce groundwater use and energy } \\
\text { costs; it has also helped to reduce waterlogging in the upstream and improve the quality of } \\
\text { groundwater downstream. }\end{array}$ & Qureshi et al., 2010 \\
\hline $\begin{array}{l}\text { Climate smart agriculture } \\
\text { practices in cotton } \\
\text { production }\end{array}$ & $\begin{array}{l}\text { In Punjab, Pakistan, the principles of Climate Smart Agriculture (CSA) was experimented on cotton } \\
\text { farming. The results revealed that the cotton productivity can be increased with less water and } \\
\text { energy with same amount of land by applying the principles and approaches of climate smart } \\
\text { agriculture in cotton farming, which can save water and energy. }\end{array}$ & Imran et al., 2018 \\
\hline $\begin{array}{l}\text { Monitoring groundwater use } \\
\text { using remote sensing chips. }\end{array}$ & $\begin{array}{l}\text { To control ground water over extraction the government of India has recently introduced a sensor in } \\
\text { pumps in some parts in India to monitor and measure extraction of groundwater through remote } \\
\text { sensor chips installed in new solar water pumps (Gupta, 2019). Pump will be automatically stopped } \\
\text { pumping water when the water level drops below a certain limit. }\end{array}$ & Gupta, 2019 \\
\hline $\begin{array}{l}\text { Solar Agricultural Feeder } \\
\text { program }\end{array}$ & $\begin{array}{l}\text { The state government of Maharashtra has introduced Solar Agricultural Feeder, which allows farmers } \\
\text { to export surplus electricity generated by solar pumps to the state electricity grid. This has become a } \\
\text { win-win situation for farmers and governments, as well as bringing synergies between food and } \\
\text { energy. }\end{array}$ & Gambhir and Dixit, 2019 \\
\hline Electricity tariff reform & $\begin{array}{l}\text { The State government of West Bengal in India has initiated tariff reform in agriculture by installing } \\
\text { meters on all its new electric irrigation pump-sets and switched from a flat tariff per user to a } \\
\text { consumption-based tariff. }\end{array}$ & Mukherji et al., 2012 \\
\hline
\end{tabular}

team at Cambridge, has developed a computed based model "Foreseer "TM", that visualizes physical flows of water, energy, and land resources and their interactive interfaces and policy implications (Allwood et al., 2012; Bajzelj et al., 2016). Recently, a few scholars (e.g., Lee et al., 2018; Nhamo et al., 2020) have suggested a multi-criteria decision analysis (MCDA) and an analytical hierarchy (AHP) process to assess alternative options for managing trade-offs and synergies.

While the analytical frameworks and models on the nexus is growing and provide valuable insights and tools to analyse and quantify nexus (Albrecht et al., 2018; Liu et al., 2018; Nhamo et al., 2020), most of the nexus tools and models are focused on assessing trade-offs and synergies, with limited focus on governance issues particularly on cross-sectoral policy coordination. They have limited understanding of how policy and institutional factors influence decision-making across sectors and how to integrate cross-sectoral policies into the planning and decision-making process and improve policy coordination and coherence across the WEF sectors. These tools and models are highly data-intensive and time-consuming and therefore have limited use in developing countries, such as those in South Asia, where quality data is scarce. In addition, many of the underlying assumptions do not fully fit within the context of South Asia. For example, in South Asia, most of the livestock are raised under 
rain-fed conditions on pastureland and the water footprint and environmental impact is much lower than of those reared in developed countries in industrial feed (Chapagain and Tickner, 2012). Thus, the underlying assumption of the tools and models that all sources of water, whether in the form of rainfall or groundwater, are equal may not valid in all situations. Similarly, when agricultural residues or wet bagasse (a by-product of sugar mills) are used for bioenergy production that induces synergy rather than trade-offs often considered generally [International Renewable Energy Agency (IRENA), 2015].

Many of the problems arising in agriculture, water, energy, and climate, such as the excessive use of agrochemicals, pollution of air and water, and overexploitation of groundwater, are the result of misplaced policy priorities, wrong incentives, and weak governance (Pingali, 2012; Rasul, 2016). Although improving policy coherence across WEF sectors is critical, a framework which policy makers can use easily in developing countries like South Asia is still missing (Wichelns, 2017). Despite significant technological innovations and models and an increase in recognition and understanding of the importance of integrated management of the food-water-energy nexus, the prevailing technical framework is not adequate for operationalization (Weitz et al., 2017; Wichelns, 2017). There is a need for a framework which translates nexus ideas into concrete steps for governments to assess, interact, weigh up, and evaluate nexus issues, and then prioritize these issues in order to maximize synergies and minimize trade-offs.

In order to ensure optimal management of trade-offs and maximize of overall benefits, the decision-making processes need to be well-coordinated and integrated by taking into account the dynamic nature of the interactions. A nexus framework is needed to support smart, targeted policy tools that address trade-offs while sustainably increasing production, conserving natural resources, and enhancing outcomes for the poor. In this section, we outline a general framework for improving policy coherence, operationalization and policy integration across the water-energy-food sectors including processes and steps that can be used to develop coherent policies related to the water-energyfood nexus. The framework provides a generic guide on how to strengthen policy coordination and institutional harmonization in order to reduce the trade-offs and maximize the benefits between the three sectors in a sustainable way. There are two major prerequisites for using the framework. The first is to establish a cross-sectoral coordination body, and the second is to establish the criteria for assessing and prioritizing policy actions. These are summarized below before the framework itself is introduced.

\section{Establishing a Cross-Sectoral Coordination Body}

One of the most critical steps toward cross-sectoral integration is the establishment of institutional mechanisms for the coordination of policies and actions in the three sectors (Weitz et al., 2017). This is a difficult task as sectoral agencies are generally more interested in working within their sectoral silos and preserving their own identities and goals. National planning commissions have usually been responsible for coordinating this task, but planning commissions have weakened in many countries and have failed to deliver effective coordination (Rasul and Sharma, 2016). It is crucial to have a central policy coordination unit in the executive branch of government to coordinate policies, consult on policy options, and anticipate, detect, analyze, and resolve policy conflicts or inconsistencies on issues related to water, energy, and food, and thereby ensuring policy coherence between the three sectors. The core tasks of the national coordination body are likely to be to build a common vision, bring together the relevant stakeholders, facilitate the exchange of ideas, and build the capacity of the relevant agencies to plan, implement and monitor water, energy, and food related policies, strategies and activities. Another important task of this coordinating body would be to promote cross-sectoral cooperation and facilitate constructive dialog between different policy communities and to resolve policy conflicts and to set up policy review mechanisms.

Different countries have already initiated mechanisms for coordination of the food-water-energy sectors. For example, the Ethiopian Government has established a Ministry of Water, Irrigation, and Electricity to undertake a multisectoral management function for the food-water-energy nexus, including areas such as water supply and sanitation, large and medium scale irrigation and drainage, water permits and licensing, hydropower and dam safety, and electricity design and distribution (Al-Saidi and Elagib, 2017; Ministry of Water, Irrigation and Electricity, 2019). Other developing countries in Africa are also trying to merge different sectors to bring policy coherence. For example, Egypt has established a Ministry of Water Resources and Irrigation and Namibia a Ministry of Agriculture, Water and Forestry. In South Asia, Nepal recently established a Ministry of Energy, Water Resources and Irrigation to oversee the joint development of the three sectors. In India, three Ministries realized that they were running overlapping programs: the Mahatma Gandhi National Rural Employment Guarantee Scheme (MGNREGS) operated by the Ministry of Rural Development, the P. M. Krishi Sinchayee Yojana irrigation project operated by the Ministry of Agriculture and Farmer's Welfare, and the Integrated Watershed Management Program (IWMP) run by the Ministry of Water Resources. Although the focus of each program was different-agriculture, water, energy and the environment-the sectors overlapped and the Ministries decided to integrate their programs to avoid duplication and make the activities more sustainable, climate resilient and cost effective.

The overall coordination, however, may remain under the cabinet or the national planning commission (which has the authority to mobilize sectoral ministries and agencies), or under an inter-ministerial committee. This may vary considerably from country to country depending on the cultural context and administrative and operational capacity (Turnpenny et al., 2008). However, it is critically important to identify a key coordinating agency within the current institutional framework, which has the authority to convene and coordinate multisectoral actions and guide integrated planning. The coordinating body should have a broad representation and may include 
political leaders and experts in the relevant fields, and should have the appropriate convening and decision-making powers and authority, as well as the capacity to deal with strategic issues, including policy coordination. This requires a continuous process of analyzing, balancing, and prioritizing the objectives of different policy goals. It may also require enhancing institutional capacity, including the operational and coordination skills of coordination agencies, and improving processes that facilitate engagement with stakeholders beyond governments (Emerson et al., 2012). In striving to establish multi-sectoral coordination, it is also important to distribute responsibility and establish mechanisms for regular interaction between key stakeholders in order to build inter-organizational trust and promote communication and sharing of knowledge and information among key institutional agencies.

\section{Fundamental Criteria for Assessing and Prioritizing Policy Actions}

The keys to addressing the nexus are policy coherence and institutional harmonization, and these depend in turn on assessing the three criteria of synergies (co-benefits), trade-offs (externalities), and neutrality. The assessment of these criteria is an important mechanism for strengthening horizontal and vertical integration between the water, energy and food sectors (Nilsson et al., 2012).

\section{Synergies or Co-benefits}

Synergies or co-benefits are experienced when the policies or actions in one sector lead to more than additional (synergies) or similar benefits (co-benefits) in achieving the goals of another sector. For example, increasing agricultural water use efficiency can free up water for other uses, including energy generation, thus providing co-benefits to both the water and energy sectors.

\section{Negative Interaction or Trade-Offs (Externalities)}

Negative interaction or trade-offs (externalities) are experienced when the policies or actions in one sector reduce the chances of achieving the goals in another sector. For example, a policy for promoting water intensive groundwater irrigation can increase both energy and water demand, and thus undermine the goals of the energy and water sectors.

\section{Neutrality Is Experienced}

Neutrality is experienced when the policies or actions in one sector have no significant influence on other sectors. For example, a policy for replacing diesel-operated irrigation pumps with solar pumps may not have any significant effect on the water or food sectors, although it may provide co-benefits to the energy sector.

\section{The Generic Framework}

A clear framework is needed to move from a sectoral to a holistic approach. Development of a detailed framework is beyond the scope of this article, rather we have outlined a generic framework for operationalization and implementation of an integrated approach to addressing the water-energy-food nexus. The four key elements and supporting structures are shown in Figure 1. The framework is intended to facilitate assessment of the food-water-energy nexus using the three broad criteria outlined above. These three criteria are at the center of the framework and related to all five steps. The framework is intended to stimulate critical thinking on developing a foodwater-energy coordination mechanism rather than providing definitive answers. The individual elements are described in more detail in the following sections.

\section{Harmonizing Policy Goals in the Water, Energy, and Food Sectors}

To manage the nexus challenges, it is first necessary to develop and coordinate the policy goals and objectives and harmonize them across the three sectors. The primary objective of harmonization is to reach broader social goals of achieving water, energy and food security while minimizing trade-offs and cross sectoral conflicts and maximizing synergies across the three sectors. As the water, energy and food sectors depend on each other for resources, policy actions or objectives in one sector interacts with those in other sectors by either providing preconditions for the realization of the objectives in other sectors, or by imposing conditions or constraints on what can be achieved in the other sectors (Nilsson et al., 2012; Scott, 2017; Weitz et al., 2017). For example, policy support to increase food production through free or subsidized electricity has triggered unsustainable extraction of groundwater and has affected the quality of electricity supply to rural areas in several States in India (Shah, 2012; Tyagi and Joshi, 2019). Similarly, increased use of inorganic fertilizers, pesticides, insecticides, and other agrochemicals driven by government incentives through subsidies has contributed to increase food production in South Asian countries, but has also accelerated the use of agrochemicals in agriculture, increased energy demand and polluted water, land and ecosystems with cascading adverse effects on fish, drinking water, land, soil, environment, and human health (Pingali, 2019).

Objectives in different sectors can also reinforce action toward objectives in other sectors (Nilsson et al., 2012; Scott, 2017; Weitz et al., 2017). In view of these interconnections and resulting trade-offs and synergies, it is important to harmonize policy objectives and policy instruments across the WEF sectors in order to minimize cross-sectoral externalities and trade-offs and maximize synergies for sustainable solutions (Bazilian et al., 2011; Pahl-Wostl, 2017; Scott, 2017; Weitz et al., 2017; Albrecht et al., 2018).

Harmonization of the policy objectives of the WEF sector, however, is a daunting task and requires the involvement of key stakeholders, the understanding of different perspectives and priorities and the development of a shared understanding of what needs to be achieved (Turnpenny et al., 2008). Both regulatory and market-based instruments need to be aligned to stimulate nexus-positive activities. While consensus on everything is not feasible or even necessary, it is possible to pursue one policy objective without undermining another. For example, improving water and energy efficiency in irrigation can serve as a winwin solution for the WEF nexus. What is needed is for the policy objectives to be coherent and for the instruments to be coordinated so that the policies are mutually supportive and not counterproductive. This calls for a clear dialog on exactly what the organization wants to achieve; it involves 


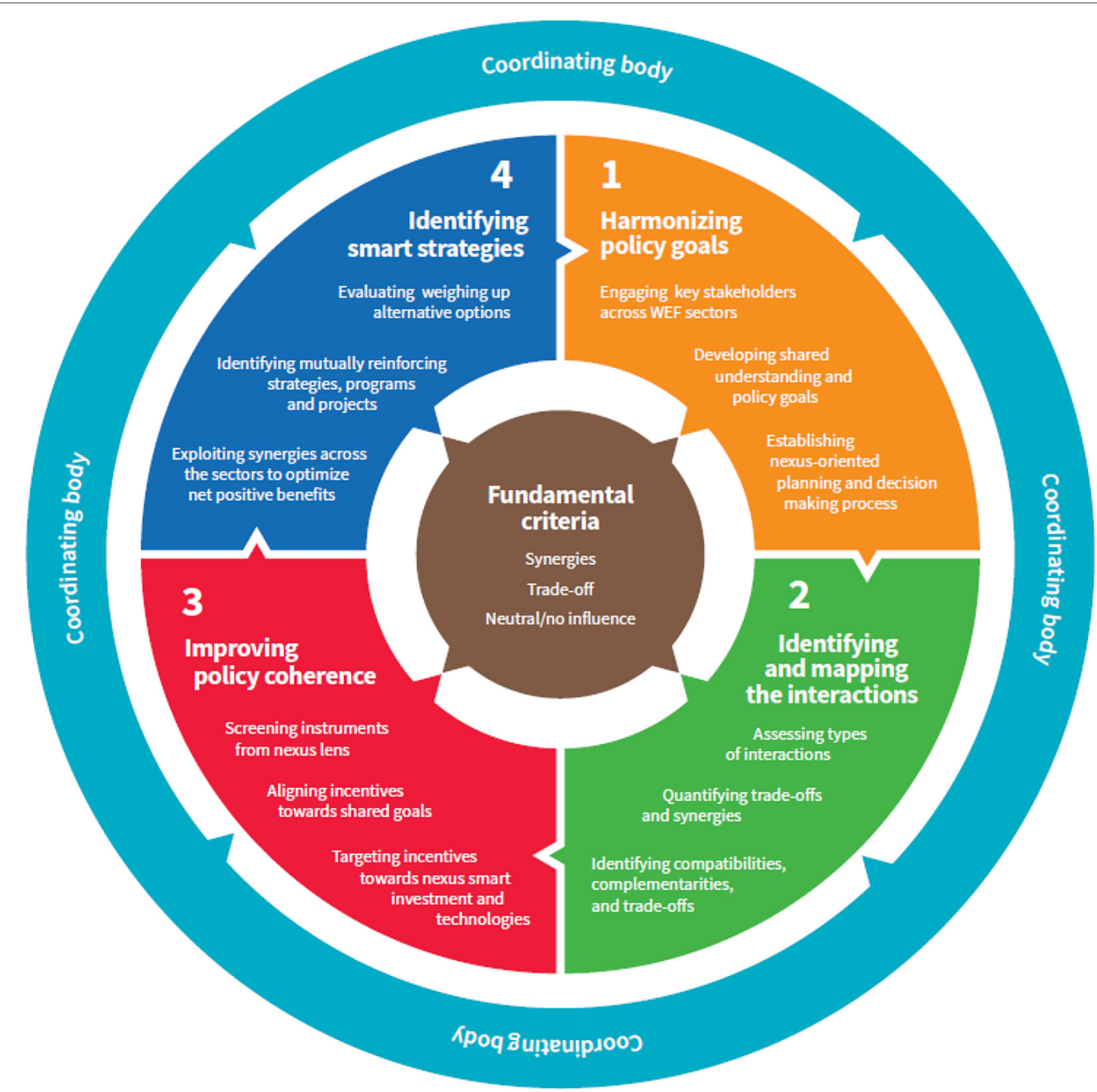

FIGURE 1 | Generic framework for operationalization of a food-water-energy nexus approach.

engagement with relevant government agencies and other key stakeholders and reaching a societal agreement on common priorities reflecting the views of key stakeholders. There is therefore a need for an appropriate harmonization strategy to enable multiple objectives to be operationalized. Harmonization of policy objectives will lead to a shared understanding of policy objectives, agreed priorities, coordinated policy frameworks and improved coherence across the WEF sectors. In addition to evaluating synergies, trade-offs and neutrality as outlined above, the following strategies can be used to harmonize policy objectives.

\section{Engaging Key Stakeholders}

In striving to build a consensus on policy goals and maintaining shared understanding, the interests, needs and positions of different stakeholders need to be understood and assessed based on the fundamental criteria outlined above. Different stakeholders may have different perspectives and priorities in the context of the water, energy, and food sectors. It is important to build trust between agencies of the three sectors and to develop a coordinated policy framework and to set up a nexus-oriented planning and decision making process. Analyzing the different perspectives using the above criteria may be useful for developing 
a shared understanding of competing objectives and priorities and may lead to buy-in to a common goal from sectoral agencies and relevant stakeholders (Stephan et al., 2018). It requires serious engagement and extensive consultation, involvement of key stakeholders from all three sectors and their interest in developing policies and strategies. Actors involved in mapping may play an important role in the development of common objectives and developing cross-sectoral strategies (Wymann von Dach and Fleiner, 2019).

\section{Agreeing on Broad Social Goals}

While each sector has a range of policy objectives, there are certain objectives that cannot be compromised, even at the cost of efficiency. For example, maintaining food production at a certain level is essential in order to avoid the risk of food insecurity, and therefore social objectives such as zero hunger cannot be compromised. Similarly, policies to ensure the provision of a basic quantity of safe drinking water and water for hygiene and sanitation cannot be compromised, even if this means, for example, sacrificing the generation of hydroelectric power. Looking at higher policy objectives, which cannot be compromised, each sector can help to develop shared policy objectives for the three sectors. While different sectors and agencies have different interests and priorities, facilitating discussion and consultation, mediating conflicts, building trust, and providing a platform to clarify expectations can enhance mutual understanding and align interests. One way to align multiple perspectives and build shared understanding through the process of engagement is known as "principled engagement" which fosters reasoned arguments (by weighing different options and priorities objectively against broad social goals) and deliberation focused on defining problems and finding agreements together (Emerson et al., 2012). It supports shared representation and open interactions of different sectoral actions to integrate the concerns and goals of different sectors and agencies. It allows open discussions, multiple perspectives, and enables "shared motivation" that builds trust, fosters mutual recognition of interdependence and shared ownership, and creates a sense of internal legitimacy (Emerson et al., 2012). The principled engagement and shared motivation support each other in creating an enabling environment for integrated planning that jointly identify and define objectives, as well as in collaborating and raising awareness about the complementarities and externalities. It also enables the use of a coordinated approach to consultation, with open communication and exchange of information, which will help align multiple perspectives, increase understanding and reduce disagreements.

\section{Identifying and Mapping the Interactions Among Sectoral Policies}

The second step is exploring and mapping the interactions of sectoral policies within the water, energy, and food sectors, and examining their characteristics, directions and magnitude. It is important to explore complementarities and identify potential co-benefits of the different policy options that bring synergistic effects by achieving multiple objectives at the same time with benefits for water, energy, and food. Mapping the existing policies and agencies involved, and understanding the interaction and degree of integration and complementarities between policies and actions in one sector with other sectors, is key to unlocking their full potential.

\section{Assessing Types of Interactions}

The assessment of the types of interactions involves the identification of the main types of interactions, the policy domains they interact with, and the assessment of the nexus interactions in different policy domains. It is also necessary to assess the direction of policy linkages and interactions to identify, quantify and manage trade-offs while at the same time exploiting synergies across the sectors (Antwi-Agyei et al., 2017). Table 3 shows an illustrative example of a qualitative assessment of the different policy options for maximizing complementary effects and minimizing counter-productive impacts with a view to enhancing net societal benefits. The cross-sectoral synergies, trade-offs and neutrality of the policy interactions provide a qualitative and numerical basis for assessment of policy options. Priority should be given to policy options that bring synergistic effects with other strategic objectives and enhance net positive benefits.

\section{Improving Policy Coherence Across WEF Sectors}

Once cross-sectoral interactions have been identified, it is important to improve policy coherence-vertical and horizontal consistency across WEF policies-to ensure that progress in one sector is not achieved at the expense of progress in other sectors. The choice of instruments is critically important in improving policy coherence. Governments can use different policy instruments (financial, regulatory and market tools used to influence people's choices and behavior) and shape the incentive structure to achieve the desired social objectives. In order to improve policy coherence and eliminate inconsistencies, policy instruments and structured incentives need to be aligned with the shared objectives of the WEF sectors.

\section{Screen Policy Instruments From Nexus Lens}

One way to align policy instruments is to screen tools from a nexus lens, to weigh and evaluate policy instruments to assess their compatibility so that the policy instruments of one objective do not undermine those of another. For example, providing incentives to promote biofuel replacing food crops for enhancing energy supply may increase energy security but may hinder the goal of achieving food security. Similarly, policies to subsidize chemical fertilizers and pesticides to increase crop productivity could result in water and air pollution and thus also defeat the goal of achieving water and energy security (Antwi-Agyei et al., 2017). The choice of policy instruments needs to consider the direction of policy linkages and adjust in such a way that the desired influence and the shared goal of WEF can be achieved.

\section{Aligning Policy Instruments}

To improve policy coherence, the best policy instruments need to be chosen and strategies and instruments need to be aligned to maximize the potential for success in achieving the shared goals, in addition to the fundamental criteria 
TABLE 3 | Illustrative example of a qualitative assessment of nexus interactions of different policy options and actions.

\begin{tabular}{|c|c|c|c|c|c|}
\hline \multirow[t]{2}{*}{ Policy actions } & \multicolumn{3}{|c|}{ Cross-sectoral effects } & \multicolumn{2}{|r|}{$\begin{array}{l}\text { Other societal and environmental } \\
\text { effects (positive/negative) }\end{array}$} \\
\hline & Water & Energy & Food & Short & Long \\
\hline Subsidies for agrochemicals & - & - & + & $+/-$ & $\begin{array}{l}\text { - } \\
\text { Long-term loss of productivity of land and water } \\
\text { and threat to agricultural sustainability }\end{array}$ \\
\hline Subsidies for energy for ground water irrigation & - & - & + & $+/-$ & $\begin{array}{l}\text { - } \\
\text { Overexploitation of ground water poses risk to } \\
\text { water and food security }\end{array}$ \\
\hline $\begin{array}{l}\text { Policy support for improving efficiency in water and } \\
\text { energy use in food production }\end{array}$ & + & + & + & + & $\begin{array}{l}+ \\
\text { Win-win-win situation }\end{array}$ \\
\hline Free or subsidized water for irrigation & - & - & + & $+/-$ & $\begin{array}{l}\text { - } \\
\text { Change of cropping patterns toward water } \\
\text { intensive crops } \\
\text { Reduced crop diversity } \\
\text { Increased cost of lifting groundwater } \\
\text { Overuse of water and energy } \\
\text { Inefficient management of irrigation systems } \\
\text { Waterlogging and salinization of soils } \\
\text { Increased methane emissions }\end{array}$ \\
\hline $\begin{array}{l}\text { Withdrawing policy support from water and energy } \\
\text { intensive crops }\end{array}$ & + & + & $+/-$ & + & $\begin{array}{l}+ \\
\text { Appropriate cropping pattern, sustainable } \\
\text { agriculture and natural resources }\end{array}$ \\
\hline Policy measures to reduce food waste & + & + & + & + & $\begin{array}{l}+ \\
\text { Reduces methane emission } \\
\text { Decreases carbon footprint } \\
\text { Reduces energy consumption from manufacturing } \\
\text { and transportation of foods }\end{array}$ \\
\hline Moving from single to multipurpose WEF project & + & + & + & + & + \\
\hline
\end{tabular}

+, synergetic; -, conflicting, +/-, both positive and negative.

presented in 5.2. This will also require the screening of policy instruments from a nexus lens. The aim is both to align strategies and to converge incentive structures in order to find mutually reinforcing strategies and instruments. The incentive structures then need to be converged and reoriented toward promoting water and energy saving technologies and encouraging investments that enhance their efficiency, while avoiding policy distortions toward water and energy intensive food production (Rasul, 2016). There are several qualitative and quantitative tools available for weighing up the policy instruments. While important trade-offs can be qualitatively identified through critical arguments using the framework developed above, calculating the actual interactions, synergies, and trade-offs requires numerical methods. Developing a causalchain analysis and trends, using an integrating index, assigning weights and performing benefit-cost analyses (BCAs) can all be used in quantitative analyses to evaluate the policy instruments.

\section{Managing Externalities}

Another way to improve policy coherence is to manage externalities. An externality arises when one action influences the outcome of another action, either positively or negatively. For instance, improving land management and less input agriculture can provide positive benefits to both water and energy. This is a positive externality. On the other hand, when agrochemicals pollute water sources and affect fisheries negatively, it is a negative externality. Externalities arise when decision in a sector regarding production or consumption of goods or services do not take into account potential consequences to other relevant sectors-whether positive (beneficial) or negative (harmful). For instance, over-extraction of ground water for producing food, which leads to overexploitation of natural resources and degradation of ecosystems. The conventional market mechanism cannot reflect the true costs and benefits of such externalities. Governments can influence and shape the incentive structure through policy instruments to achieve the desired social goals of WEF. Appropriate policy instruments need to be established and incentive structures need to be reoriented to correct market failures and internalize external costs. When incentives are not enough, regulatory instruments are important to regulate unsustainable use of resources and protect the natural resources critical for WEF security and environmental sustainability.

\section{Identifying Smart Strategies That Bring Synergistic Effects}

Once synergies, trade-offs, compatibility, and congruence are assessed, the final step is to weigh and evaluate the merits and demerits of various policy options and strategies, and identify smart strategies that bring synergistic effects. It involves the screening of programs, projects and investments from the WEF nexus lens, and weighs and evaluates them on the basis of the three basic criteria set out above. 


\section{Screening Programs, Projects, and Investments}

A detailed screening matrix is developed from a defined set of water, energy, and food indicators proposed in earlier steps to show the synergies and trade-offs between selected policy objectives. Such a matrix provides information about the direction and magnitude of the proposed projects and investments (Boas et al., 2016). This rigorous screening process helps review and revise incentive structures toward nexus friendly programs and provides suggestions where there is a need to improve existing mechanisms to increase the resource use efficiency. Policy choices that breaks sectoral silos and improves policy coherence, enhances synergies and co-benefits across WEF sectors, improves productivity, reduces cross-sectoral externalities, and trade-offs should get prioritized (Bazilian et al., 2011). Policy support and incentive structures need to be targeted at nexus smart investment and technologies to exploit synergies and minimize trade-offs.

\section{Optimizing Net Positive Benefits}

While in certain areas policy cannot be compromised, there are many areas where improving policy coherence and coordination can reduce trade-offs and improve synergies and the net positive outcome for societies. It is therefore crucial to assess the magnitude of trade-offs and find ways and means to minimize them while improving the net positive outcome for water, energy and food security. For example, reducing pesticides in agriculture may reduce productivity, but if this is compensated by increased fish production and/or better water quality for domestic use, the net positive benefit may increase. This approach can be useful in identifying alternative approaches and combinations of measures to maximize synergies and minimize trade-offs in meeting the competing demands for resources requirements across the three sectors. This can also help in identifying leverage points that can generate co-benefits to maximize net social benefits in achieving the broad social objectives.

\section{CONCLUSIONS}

The proposed framework helps to identify steps and processes for cross-sectoral coordination in planning and implementing the water-energy-food nexus approach and suggests criteria to be used to initiate consultation and dialogue across the sectors. Rigorous application of the four-step framework, including screening of projects using nexus-based indicators, will help to prioritize policy decisions, actions, policies, and resource allocation across the water, energy, and food sectors and intraorganizational collaboration.

The framework identifies four key steps for operationalizing the water, energy, and food nexus approach: (a) harmonizing policy goals in the three sectors, (b) identifying and mapping the interactions of sectoral policies, (c) assessing the compatibility of sectoral policies and strategies with nexus objectives, (d) identifying smart strategies that bring synergetic effects across WEF sectors. Each of these steps is carried out using assessments based on three broad criteria-synergies (co-benefits), trade-offs (externalities), and neutrality-while also taking into account broad social goals. One of the key elements of the framework is a common cross-sectoral coordination body that operationalizes the proposed steps. This approach can serve as a first step toward moving away from sector- specific silos and building a common ground to facilitate consensus on prioritizing activities across the water, energy, and food sectors. The framework can also help to align policies and strategies across sectors and to develop overarching strategies. By addressing the tradeoffs, a long-term, concerted, and sustained strategy can be developed and applied to achieve resource security. Although the framework is targeted at macro level policy planning, the principles and criteria can also be used in meso and micro level nexus programs and actions. It provides a step-by-step approach and practical guideline to facilitate exchange across and within sectors, to harmonize policies and strategies, to identify needs and priorities, to establish synergies, and to allocate limited resources.

The framework is expected to help governments in coordinating the actions of diverse actors across the water, energy, and food sectors and designing policies and programs that address trade-offs, while increasing production sustainably, conserving natural resources, and enhancing food-water-energy nexus outcomes. It can help encourage efficient use, and more efficient allocation, of resources across the sectors and thus enable progress to be made toward the three SDGs of zero hunger (SDG 2), clean water and sanitation (SDG 6), and affordable and clean energy (SDG 7). It can also support adaptation to the increasing challenges being brought by COVID-19 in terms of the need for increased supplies of water for hygiene and sanitation (Rasul, 2020). The extent to which this framework can mitigate cross-sectoral conflicts will depend on the capacity of the cross- sectoral coordination body to raise awareness about the benefits of the nexus approach and bring the actors together on a common ground that maximizes net benefits in the nexus outcome. The starting point could be analysis of the existing policies, strategies, and instruments using a food-energy-water nexus lens, and identifying the gaps and conflicts, trade-offs, and possible synergistic benefits of harmonization. Future projects and programs should be screened using the criteria suggested in the framework to build a consensus on priority projects and activities.

The proposed framework is generic and can be further developed using quantitative tools for detailed analysis and quantification of cross-sectoral trade-offs, externalities, and synergies. It also needs to make it possible for the environment and institutional arrangements, as well as the political will, to make nexus solutions work effectively. Further research is needed for cross-sectoral assessment to quantify trade-offs and synergies and to develop a systematic understanding. More research is also needed on institutional innovation, stakeholder engagement, and building trust for the operationalization of the water-energy-food nexus approach at the local level.

\section{AUTHOR CONTRIBUTIONS}

GR: conceptualizing, collecting information, writing, and revising. NN: collecting information, writing, and revising. 
All authors contributed to the article and approved the submitted version.

\section{FUNDING}

This study was conducted under Koshi Basin Program (KBP) at the International Center for Integrated Mountain Development (ICIMOD) and contributes to the Sustainable Development Investment Portfolio (SDIP) which is supported by the Australian Government [SDIP2 72862]. ICIMOD gratefully acknowledges the support of its core donors: the Governments of Afghanistan, Australia, Austria, Bangladesh, Bhutan, China,

\section{REFERENCES}

Ahmed, I., Al-Othman, A. A., and Umar, R. (2013). Is shrinking groundwater resources leading to socioeconomic and environmental degradation in Central Ganga Plain, India? Arabian J. Geosci. 7, 4377-4385. doi: 10.1007/s12517-013-1058-3

Alauddin, M., and Quiggin, J. (2008). Agricultural intensification, irrigation and the environment in South Asia: issues and policy options. Ecol. Econo. 65, 111-124. doi: 10.1016/j.ecolecon.2007.06.004

Albrecht, T., Crootof, R., and Scott, C. (2018). The water-energy-food nexus: a systematic review of methods for nexus assessment. Environ. Res. Lett. 13:043002. doi: 10.1088/1748-9326/aaa9c6

Allwood, J. M., Bajzelj, B., Curmi, E., Dennis, J., Fenner, R. A., Gilligan, C. A., et al. (2012). "Foreseer [Computer Software]". Available online at: www.foreseer.group.cam.ac.uk (accessed November 4, 2020).

Al-Saidi, M., and Elagib, N. A. (2017). Towards understanding the integrative approach of the water, energy and food nexus. Sci. Total Environ. 574, 1131-1139. doi: 10.1016/j.scitotenv.2016.09.046

Amjath-Babu, T. S., Sharma, B., Brouwer, R., Rasul, G., Wahid, S. M., Neupane, N., et al. (2019). Integrated modelling of the impacts of hydropower projects on the water-food-energy nexus in a transboundary Himalayan river basin. Applied energy 239, 494-503. doi: 10.1016/j.apenergy.2019.01.147

Antwi-Agyei, P., Dougill, A. J., and Stringer, L. C. (2017). Assessing coherence between sector policies and climate compatible development: opportunities for triple wins. Sustainability 9:2130. doi: 10.3390/su911213

Asaduzzaman, M., Shahabuddin, Q., Deb, U. K., and Jones, S. (2009). Input Prices, Subsidies and Farmers' Incentives. Dhaka: BIDS Policy Brief, Bangladesh Institute of Development Studies.

Atapattu, S. S., and Kodituwakku, D. C. (2009). Agriculture in South Asia and its implications on downstream health and sustainability: a review. Agric. Water Manage. 96, 361-373. doi: 10.1016/j.agwat.2008.09.028

Badiani, R., Jessoe, K., and Plant, S. (2012). Development and the environment: the implications of agricultural electricity subsidies in India. J Environ Dev. 21, 244-262. doi: 10.1177/1070496512442507

Bajzelj, B., Fenner, R. A., and Curmi, E. (2016). 2016.Teaching sustainable and integrated resource management using an interactive nexus model. Int. J. Sustain. High. Educ. 17, 2-15. doi: 10.1108/IJSHE-02-2014-0022

Barker, R., and Molle, F. (2004). Evolution of irrigation in South and Southeast Asia. Comprehensive Assessment Secretariat. Colombo: Comprehensive Assessment, Water for Food, IWMI.

Bassi, N. (2014). Assessing potential of water rights and energy pricing in making groundwater use for irrigation sustainable in India. Water Policy 16, 442-453. doi: 10.2166/wp.2013.123

Bazilian, M., Rogner, H., Howells, M., Hermann, S., Arent, D., Gielen, D., et al. (2011). Considering the energy, water and food nexus: towards an integrated modelling approach. Energy Policy 39, 7896-7906. doi: 10.1016/j.enpol.2011.09.039

Beaton, C., Jain, P., Govindan, M., Garg, V., Murali, R., Roy, D., et al. (2019). Mapping Policy for Solar Irrigation Across the Water-Energy-Food (WEF) Nexus in India. International Institute for Sustainable Development. Available online at: http://www.indiaenvironmentportal.org.in/files/file/solar-irrigationacross-wef-nexus-india.pdf (accessed March 25, 2019).
India, Myanmar, Nepal, Norway, Pakistan, Sweden, and Switzerland. The views and interpretations in this paper are those of the authors and are not necessarily attributable to ICIMOD or its member countries.

\section{ACKNOWLEDGMENTS}

The authors would like to extend thanks to three reviewers and the handling editor for constructive comments and suggestions. The earlier version of the paper was presented at the 3rd World Irrigation Forum (WIF) in September 2019 in Bali, Indonesia.

Bizikova, L., Roy, D., Swanson, D., Venema, H. D., and McCandless, M. (2013). The Water-energy-food Security Nexus: Towards a Practical Planning and Decisionsupport Framework for Landscape Investment and Risk Management. Winnipeg, CA: IISD.

Boas, I., Biermann, F., and Kanie, N. (2016). Cross-sectoral strategies in global sustainability governance: towards a nexus approach. Int. Environ. Agreements 16, 449-464. doi: 10.1007/s10784-016-9321-1

Branche, E. (2017). The multipurpose water uses of hydropower reservoir: the SHARE conceptLe multi-usage de l'eau des réservoirs hydroélectriques à buts multiples: Le concept SHARE. Comptes Rendus Physique 18, 469-478. doi: 10.1016/j.crhy.2017.06.001

Cai, Y., Bandara, J. S., and Newth, D. (2016). A framework for integrated assessment of food production economics in South Asia under climate change. Environ. Model. Softw. 75, 459-497. doi: 10.1016/j.envsoft.2015. 10.024

Calatrava, J., and Martínez-Granados, D. (2018). Water buybacks to recover depleted aquifers in south-east Spain. Int. J. Water Resour. Dev. 35, 977-998. doi: 10.1080/07900627.2018.1504756

Chapagain, A. K., and Tickner, D. (2012). Water footprint: help or hindrance? Water Alt. 5, 563-581. Availanle online at: http://www.water-alternatives.org/ index.php/all-abs/186-a5-3-2/file

Emerson, K., Nabatchi, T., and Balogh, S. (2012). An integrative framework for collaborative governance. J. Public Administr. Res. Theor. 22, 1-29. doi: 10.1093/jopart/mur011

FAO (2011). The State of the World's Land and Water Resources for Food and Agriculture. Rome: FAO.

FAO (2012). Irrigation in Southern and Eastern Asia in Figures AQUASTAT Survey - 2011. FAO Water Reports 37. Rome: Food and Agriculture Organization of the United Nations.

FAO (2014). The Water-Energy-Food Nexus: A New Approach in Support of Food Security and Sustainable Agriculture. Rome: FAO.

FAO (2016). AQUASTAT Main Database. Food and Agriculture Organization of the United Nations (FAO). Availanle online at: http://www.fao.org/aquastat/en/ databases/ (accessed May 3, 2019).

FAO (2018). State of Food and Agriculture in Asia and the Pacific Region, Including Future Prospects and Emerging Issues. Availanle online at: http://www.fao.org/ 3/mw252en/mw252en.pdf (access May 7, 2019).

FAO (2019). Global Hunger Index, the Challenge of Hunger and Climate Change. Rome: FAO.

Gambhir, A., and Dixit, S. (2019). Powering agriculture via solar feeders. Water Energy Int. 62, 31-32.

Gandhi, V. P., and Namboodiri, N. V. (2009). Groundwater Irrigation in India: Gains, Costs and Risks. Working Paper No. 2009-03-08 (Ahmedabad: Indian Institute of Management).

Garrick, D., Siebentritt, M. A., Aylward, B., Bauer, C. J., and Purkey, A. (2009). Water markets andfreshwater ecosystem services: Policy reform and implementation in the Columbia and Murray-Darling Basins. Ecol. Econ. 69, 366-379. doi: 10.1016/j.ecolecon.2009.08.00

Gerbens-Leenes, W., and Hoekstra, A. (2011). The water footprint of biofuel-based transport, Energy Environ. Sci. 4:2658. doi: 10.1039/c1ee01187a

Giampietro, M., Aspinall, R., Bukkens, S., Benalcazar, J. C., Diaz-Maurin, F., Flammini, A., et al. (2013). An Innovative Accounting Framework for the 
Food-Energy-Water Nexus: Application of the MuSIASEM Approach to Three Case Studies. Rome: FAO Publications.

Gilbert, N. (2012). One-third of our greenhouse gas emissions come from agriculture. Nature News 31. doi: 10.1038/nature.2012.11708 Availanle online at: https://www.nature.com/news/one-third-of-our-greenhouse-gasemissions-come-from-agriculture-1.11708 (accessed November 25, 2019).

Gulati, A., Ferroni, M., and Zhou, Y. (2018). Supporting Indian Farms the Smart Way. Academic Foundation in Association with ICRIER, India. Available online at: http://hdl.handle.net/11540/8897 (accessed November 5, 2020).

Gupta, E. (2019). The Impact of solar water pumps on energy-waterfood nexus: evidence from Rajasthan, India. Energy Policy 129, 598-609. doi: 10.1016/j.enpol.2019.02.008

Halbe, J., and Knüppe, K. (2015). The need for policy coordination in governing the water-energy-food nexus. Change Adapt. Socioecol. Syst. 2, 82-84. doi: 10.1515/cass-2015-0009

Hasanain, A., Ahmad, S., Mehmood, M., Majeed, S., and Zinabou, G. (2012). Irrigation and Water Use Efficiency in South Asia. Briefing Paper Number 9 (New Delhi: Global Development Network).

Hatfield-Dodds, S., Adams, P. D., Brinsmead, T. S., Bryan, B. A., Chiew, F. H. S., Finnigan, J. J., et al. (2015). Australian National Outlook 2015: Economic Activity, Resource Use, Environmental Performance and Living Standards 1970-2050. Canberra, ACT: CSIRO.

Hermann, S., Welsch, M., Segerstrom, R. E., Howells, M. I., Young, C., Alfstad, T., et al. (2012). Climate, land, energy and water (CLEW) interlinkages in Burkina Faso: an analysis of agricultural intensification and bioenergy production. Nat. Resour. Forum 36, 245-262. doi: 10.1111/j.1477-8947.2012.01463.x

Hoekstra, A., and Mekonnen, M. (2012). The water footprint of humanity. Proc. Natl. Acad. Sci. U.S.A. 109, 3232-3237. doi: 10.1073/pnas.1109936109

IAEA (2009). Seeking Sustainable Climate, Land, Energy and Water (CLEW) Strategies. Vienna: International Atomic Energy Agency.

ICIMOD (2020). COVID-19 Impact and Policy Responses in the Hindu Kush Himalaya. Kathmandu: International Centre for Integrated Mountain Development. Available online at: https://lib.icimod.org/record/34863 (accessed December 10, 2020).

IFPRI (2007). Power and Irrigation Subsidies in Andhra Pradesh and Punjab. Washington DC: International Food Policy Research Institute.

Imran, M., Ali, A., Ashfaq, M., Hassan,S., Culas R, and Ma, C. (2018). Impact of Climate Smart Agriculture (CSA) practices on cotton production and livelihood of Farmers in Punjab, Pakistan. Sustainability 10:2101. doi: 10.1016/j.apenergy.2017.08.243

International Energy Agency (2019). World Energy Outlook 2019. Flagship Report. Paris: Intenational Energy Agency.

International Institute for Sustainable Development (2013). The Water-EnergyFood Security Nexus: Towards a Practical Planning and Decision-Support Framework for Landscape Investment and Risk Management. International Institute for Sustainable Development.

International Renewable Energy Agency (IRENA) (2015). Renewable Energy and the Water, Energy and Food Nexus. Available online at: www.irena.org/ documentdownloads/publications/irena_water_energy_food_nexus_2015.pdf (accessed November 25, 2019).

Kaddoura, S., and El Khatib, S. (2017). Review of water-energy-food nexus tools to improve the nexus modelling approach for integrated policy making. Environ. Sci. Policy 77, 114-121. doi: 10.1016/j.envsci.2017.07.007

Karnib, A. (2017). A quantitative nexus approach to analyze the interlinkages across the sustainable development goals. J. Sustain. Dev. 10, 173-180. doi: 10.5539/jsd.v10n5p173

Karnib, A. (2018). Bridging science and policy in water-energy-food nexus: using the Q-nexus model for informing policy making. Water Resour. Manage. 32, 4895-4909. doi: 10.1007/s11269-018-2059-5

Katz, S., Padowski, J.,Goldsby, M., Brady, M., and Hampton, S. (2020). Defining the nature of the nexus: specialization, connectedness, scarcity, and scale in food-energy-water management. Water 12:972. doi: 10.3390/w12040972

Khan, S., and Hanjra, M. (2009). Footprints of water and energy inputs in food production - global perspectives. Food Policy 34,130-140, doi: $10.1016 /$ j.foodpol.2008.09.001

Kumar, M., Scott, C., and Singh, O. (2011). Inducing the shift from flat-rate or free agricultural power to metered supply: implications for groundwater depletion and power sector viability in India. J. Hydrol. 409, 382-394. doi: 10.1016/j.jhydrol.2011.08.033
Kumar, M.D. (2016). Distressed elephants: policy initiatives for sustainable groundwater management in India. IIM Kozhikode Soc. Manage. Rev. 5, 51-62. doi: $10.1177 / 2277975215617266$

Lal, R. (2011). "Soil degradation and food security in South Asia," in Climate Change and Food Security in South Asia, eds R. Lal, M. V. K. Sivakumar, M. A. Faiz, A. H. M. Mustafizur Rahman, and K. R. Islam (Dordrecht; Heidelberg; New York, NY; London: Springer), 600. doi: 10.1007/978-90-481-9516-9_10

Leck, H., Conway, D., Bradshaw, M., and Rees, J. (2015). Tracing the waterenergy-food nexus: description, theory and practice. Geography Compass 9, 445-460.doi: 10.1111/gec3.12222

Lee, M., Yu, C., Chiang, P., and Hou, C. (2018). Water-energy nexus for multicriteria decision making in water resource management: a case study of Choshui River Basin in Taiwan. Water 10:1740. doi: 10.3390/w10121740

Lele, U., Klousia-Marquis, M., and Goswami, S. (2013). Good governance for food, water and energy security. Aquat. Proc. 1, 44-63. doi: $10.1016 /$ j.aqpro.2013.07.005

Liu, J., Hull, V., Godfray, H. C. J., Tilman, D., Gleick, P., Hoff, H., et al. (2018). Nexus approaches to global sustainable development. Nat. Sustain. 1, 466-476. doi: 10.1038/s41893-018-0135-8

Liu, J., Scanlon, B., Zhuang, J, and Varis, O. (2020). Food-energy-water nexus for multi-scale sustainable development. Resourc. Conservat. Recycling 154:104565. doi: 10.1016/j.resconrec.2019.104565

Liu, J., Yang, H., Cudennec, C., Gain, A. K., Hoff, H., Lawford, R., et al. (2017). Challenges in operationalizing the water-energy-food nexus. Hydrol. Sci. J. 62, 1714-1720. doi: 10.1080/02626667.2017.1353695

Liu, W., Yang, H., Tang, Q., and Liu, X. (2019). Understanding the water-food-energy nexus for supporting sustainable food production and conserving hydropower potential in China. Front. Environ. Sci. 7:50. doi: 10.3389/fenvs.2019.00050

Malik, R. P. S. (2016). Falling water tables-sustaining agriculture. The challenges of groundwater management in India. INDAS South Asia Work. Papers 17, 1-13. Available online at: http://hdl.handle.net/2433/231398

Markantonis, V., Reynaud, A., Karabulut, A., El Hajj, R., Altinbilek, D., Awad, I. M., et al. (2019). Can the Implementation of the water-energy-food nexus support economic growth in the Mediterranean Region? The current status and the way forward. Front. Environ. Sci. 7:84. doi: 10.3389/fenvs.2019.00084

Mellah, T. (2018). Effectiveness of the water resource allocation institution in Tunisia. Water Policy 20, 429-445. doi: 10.2166/wp.2018.067

Ministry of Water, Irrigation and Electricity (2019). Ministry of Water, Irrigation and Electricity. Available online at: http://mowie.gov.et/ (accessed June 10, 2020).

Mohtar, R. H., and Daher, B. (2016). Water-energy-food nexus framework for facilitating multi-stakeholder dialogue. Water Int. 41, 655-661. doi: 10.1080/02508060.2016.1149759

Mukherji, A., Sarkar, A., Das, A., Chanana, N., Shah, T., and Malik, R. (2011). Energy, Agriculture and Groundwater Nexus in Punjab. New Delhi: International Water Management Institute.

Mukherji, A., Shah, T., and Giordano, M. (2012). Managing energy-irrigation nexus in India: a typology of state interventions. IWMI Tata Water Policy Res. Highlight 36:9. Available online at: https://hdl.handle.net/10568/38994 (accessed March 11, 2019).

Nhamo, L., Mabhaudhi, T., Mpandeli, S., Dickens, C., Nhemachena, C., Senzanje, A., Naidoo, D., et al. (2020). An integrative analytical model for the waterenergy-food nexus: South Africa case study. Environ. Sci. Policy 109, 15-24. doi: 10.1016/j.envsci.2020.04.010

Nhamo, L., Ndlela, B., Nhemachena, C., Mabhaudhi, T., Mpandeli, S., and Matchaya, G. (2018). The water-energy-food nexus: climate risks and opportunities in Southern Africa. Water 10:567. doi: 10.3390/w100 50567

Nilsson, M., Zamparutti, T., Petersen, J. E., Nykvist, B., Rudberg, P., and McGuinn, J. (2012). Understanding policy coherence: analytical framework and examples of sector-environment policy interactions in the EU. Environ. Policy Governance 22, 395-423. doi: 10.1002/eet.1589

OECD (2014). Global Forum on Environment: New Perspectives on the WaterEnergy-Food-Nexus. Available online at: http://www.oecd.org/environment/ nexus.htm (accessed January 3, 2020).

Pahl-Wostl, C. (2017). Governance of the water-energy-food security nexus: a multi-level coordination challenge. Environ. Sci. Policy 92, 356-367. doi: 10.1016/j.envsci.2017.07.017 
Palanisami, K., Mohan, K., and Kakamanu, K. R. (2011). Spread and economics of micro-irrigation in India: evidence from nine states. Econ. Political Weekly 46, 81-86. Available online at: https://www.jstor.org/stable/23018814

Pingali, P. (2007). Agricultural growth and economic development: a view through the globalization lens. Agri. Econ. 37, 1-12. doi: 10.1111/j.1574-0862.2007.00231.x

Pingali, P. (2012). Green revolution: impacts, limits, and the path ahead. Proc. Natl. Acad. Sci. U.S.A. 109, 12302-12308. doi: 10.1073/pnas.0912 953109

Pingali, P. (2015). Agricultural policy and nutrition outcomes-getting beyond the preoccupation with staple grains. Food Security 7, 583-591. doi: 10.1007/s12571-015-0461-x

Pingali, P. (2019). "Policies for sustainable food systems," in Sustainable Food and Agriculture (Academic Press), 509-521. doi: 10.1016/B978-0-12-812134-4.00045-5

Planning Commission of Pakistan (2012). Planning Commission, Government of Pakistan. Islamabad: Canal Water Pricing for Irrigation in Pakistan.

Prasad, G., Stone, A., Hughes, A., and Stewart, T. (2012). "Towards the development of an energy-water-food security nexus based modelling framework as policy and planning tool for South Africa," in Strategies to Overcome Poverty and Inequality Conference (Cape Town: University of Cape Town).

Putra, M., Pradhan, P., and Kropp, J. (2020). A systematic analysis of waterenergy-food security nexus: a South Asian case study. Sci. Total Environ. 728:138451doi: 10.1016/j.scitotenv.2020.138451

Qureshi, A. S., McCornick, P. G., Sarwar, A., and Sharma, B. R. (2010). Challenges and prospects for sustainable groundwater management in the Indus Basin, Pakistan. Water Resour. Manage. 24, 1551-1569. doi: 10.1007/s11269-009-9513-3

Ramaswami, B. (2019). Agricultural Subsidies: Study Prepared for XV Finance Commission. New Delhi: Indian Statistical Institute.

Rasul, G (2020). A framework for improving policy priorities in managing COVID-19 challenges in developing countries. Front. Public Health 8:589681. doi: $10.3389 /$ fpubh.2020.589681

Rasul, G. (2014). Food, water, and energy security in South Asia: a nexus perspective from the Hindu Kush Himalayan region. Environ. Sci. Policy 39, 35-48. doi: 10.1016/j.envsci.2014.01.010

Rasul, G. (2016). Managing the food, water, and energy nexus for achieving the sustainable development goals in South Asia. Environ. Dev. 18, 14-25. doi: 10.1016/j.envdev.2015.12.001

Rasul, G. (2021). Twin challenges of COVID-19 pandemic and climate change for agriculture and food security in South Asia. Environ. Challenges 2:100027. doi: 10.1016/j.envc.2021.100027

Rasul, G., Hussain, A., Mahapatra, B., and Dangol, N. (2018). Food and nutrition security in the Hindu Kush Himalayan region. J. Sci. Food Agric. 98, 429-438. doi: $10.1002 /$ jsfa. 8530

Rasul, G., Neupane, N., Hussain, A., and Pasakhala, B. (2019). Beyond hydropower: towards an integrated solution for water, energy and food security in South Asia. Int. J. Water Resour. Dev. 9, 1-25. doi: 10.1080/07900627.2019. 1579705

Rasul, G., Neupane, N., Pasakhala, B., Gurung, P., Nepal, A., and Sharma, E. (2020). "Deepening regional cooperation for enhancing water, energy, and food security and addressing COVID-19 challenges in the Hindu Kush Himalayan Region," in Water Resources and Economic Processes, ed T. Distefano (London: Taylor and Francis), 320. doi: 10.4324/9780429025013

Rasul, G., and Sharma, B. (2016). The nexus approach to water-energy-food security: an option for adaptation to climate change. Clim. Policy 16, 682-702. doi: 10.1080/14693062.2015.1029865

Rulli, M., Bellomi, D., Cazzoli, A., Carolis, G., and D'Odorico, P. (2016). The water-land-food nexus of first-generation biofuels. Sci. Rep. 6:22521. doi: $10.1038 /$ srep22521

Sarni, W. (2015). Deflecting the scarcity trajectory innovation at the water, energy, and food nexus. Deloitte Rev. 17, 130-147. Available online at: https://www2. deloitte.com/content/dam/insights/us/articles/water-energy-food-nexus/ DUP1205_DR17_DeflectingtheScarcityTrajectory.pdf (accessed January 5, 2021).

Schmidhuber, J., Pound, J., and Qiao, B. (2020). COVID-19: Channels of Transmission to Food and Agriculture. Rome:FAO. doi: 10.4060/ca8430en
Scott, A. (2017). Making Governance Work for Water-Energy-Food Nexus Approaches. CDKN Working Paper. Available online at: https://www. africaportal.org/publications/making-governance-work-waterenergyfoodnexus-approaches/ (accessed November 5, 2020).

Scott, C., Pierce, S., Pasqualetti, M., Jones, A., Montz, B., and Hoover, J. (2011). Policy and institutional dimensions of the water-energy nexus. Energy Policy 39, 6622-6630. doi: 10.1016/j.enpol.2011.08.013

Shah, S. (2012). Institutional Reform for Water Use Efficiency in Agriculture: International Best Practices and Policy Lessons for India. CEEW Working Paper 2012/3. New Delhi.

Shah, T., and Chowdhury, S. D. (2017). Farm power policies and groundwater markets contrasting Gujarat with West Bengal (1990-2015). Econ. Political Weekly 52, 39-47. Available online at: https://hdl.handle.net/10568/83489

Shah, T., Rajan, A., Rai, G. P., Verma, S., and Durga, N. (2018). Solar pumps and South Asia’s energy-groundwater nexus: exploring implications and reimagining its future. Environ. Res. Letters 13:115003. doi: 10.1088/1748-9326/aae53f

Shah, T., Scott, C., Kishore, A., and Sharma, A. (2004). Energy-Irrigation Nexus in South Asia: Improving Groundwater Conservation and Power Sector Viability, Vol. 70. Colombo: IWMI.

Simpson, G.B., and Jewitt, G.P. (2019). The development of the water-energy-food nexus as a framework for achieving resource security: a review. Front. Environ. Sci. 7:8. doi: 10.3389/fenvs.2019.00008

Stephan, R., Mohtar, R., Daher, B., Irujo, A., et al. (2018): Water-energy-food nexus: a platform for implementing the Sustainable Development Goals. Water Int. 43, 472-479. doi: 10.1080/02508060.2018.1446581

Turnpenny, J., Nilsson, M., Russel, D., Jordan, A., Hertin, J., and Nykvist, B. (2008). Why is integrating policy assessment so hard? A comparative analysis of the institutional capacities and constraints. J. Environ. Plan. Manage. 51, 759-775. doi: 10.1080/09640560802423541

Tyagi, N., and Joshi, P. (2019). Harmonizing the water-energy-food nexus in Haryana: an exploration of technology and policy options. INAE Lett. 4, 251-267 doi: 10.1007/s41403-019-00079-5

UNESCO (2020). The United Nations World Water Development Report 2020, Water and Climate Change. UNESCO. Available online at: www.unwater.org (accessed June 15, 2019).

United Nations (2015). "The future we want," in Outcome Document of the UN Conference on Sustainable Development (Rio+20). A/CONF.216/L.1. Available online at: https://sustainabledevelopment.un.org/futurewewant.html (accessed October 11, 2019).

United Nations (2019). SDG Progress Reports 2019: Are We on Track to Achieve the Global Goals?

United Nations Water (2018). Water, Food and Energy. Available online at: https:// www.unwater.org/water-facts/water-food-and-energy/ (accessed December $15,2019)$.

Weitz, N., Strambo, C., Kemp-Benedict, E., and Nilsson, M. (2017). Closing the governance gaps in the water-energy-food nexus: insights from integrative governance. Global Environ. Change 45, 165-173. doi: 10.1016/j.gloenvcha.2017.06.006

Wichelns, D. (2017). The water-energy-food nexus: is the increasing attention warranted, from either a research or policy perspective? Environ Sci Policy 69, 113-123. doi: 10.1016/j.envsci.2016.12.018

World Bank (2018). World Bank Online Database. Available online at: https://data. worldbank.org/indicator (accessed December 12, 2018).

Wymann von Dach, S., and Fleiner, R. (2019). Shaping the Water-Energy-Food Nexus for Resilient Mountain Livelihoods. Issue Brief on Sustainable Mountain Development. Bern: Centre for Development and Environment (CDE).

Conflict of Interest: The authors declare that the research was conducted in the absence of any commercial or financial relationships that could be construed as a potential conflict of interest.

Copyright ( 2021 Rasul and Neupane. This is an open-access article distributed under the terms of the Creative Commons Attribution License (CC BY). The use, distribution or reproduction in other forums is permitted, provided the original author(s) and the copyright owner(s) are credited and that the original publication in this journal is cited, in accordance with accepted academic practice. No use, distribution or reproduction is permitted which does not comply with these terms. 